\title{
Necrotic Enteritis by Beta2toxin-Producing Clostridium perfringens in Doom Pigs of Assam, India
}

\author{
Md. Iftikar Hussain ${ }^{1,4}$, Probodh Borah ${ }^{3,4}$, Isfaqul Hussain ${ }^{6}$, \\ Rajeev Kumar Sharma ${ }^{5}$ and Mohan Chandra Kalita ${ }^{2}$ \\ ${ }^{1}$ Department of Bioengineering and Technology, ${ }^{2}$ Department of Biotechnology, Gauhati \\ University, Assam, India \\ ${ }^{3}$ Department of Animal Biotechnology, ${ }^{4}$ State Biotech Hub, ${ }^{5}$ Department of Veterinary \\ Microbiology, College of Veterinary Science, AAU, Assam, India \\ ${ }^{6}$ Division of Veterinary Microbiology and Immunology, FVSc and AH, \\ SKUAST-Kashmir, J\&K, India \\ *Corresponding author email id:
}

\begin{tabular}{|c|c|}
\hline & A B S T R A C T \\
\hline Keywords & \multirow{4}{*}{$\begin{array}{l}\text { Piglet diarrhoea caused by beta2 toxin producing Clostridium perfringens is a serious } \\
\text { problem to piggeries throughout the world. The newly recognized Doom breed of Assam, } \\
\text { India can survive under poor rearing condition and is generally found to be disease } \\
\text { resistant. Beta2 toxin was earlier reported to be associated with necrotic enteritis in piglets } \\
\text { of different breeds but its role has not so far been reported in Doom breed. Two cases of } \\
\text { piglet diarrhoea in their post mortem analysis were found to be havingsevere lesions of } \\
\text { necrotic enteritis in their intestine. Bacterial isolation followed by biochemical and } \\
\text { molecular analysis confirmed theirassociation with } C \text {. perfringens Type A possessing } \\
\text { beta2 gene. Further, to findout the total } C \text {. perfringens load under such severe condition, it } \\
\text { was quantified by qPCR anda maximum of } 2 \times 10^{6} \text { fold incerease was observed compared } \\
\text { to thereported load for healthy piglets. }\end{array}$} \\
\hline $\begin{array}{l}\text { Doom pig, Nectrotic } \\
\text { enteritis, qPCR, } \\
\text { Multiplex, Beta2 }\end{array}$ & \\
\hline Article Info & \\
\hline $\begin{array}{l}\text { Accepted: } \\
\text { 19 April } 2017 \\
\text { Available Online: } \\
10 \text { May } 2017\end{array}$ & \\
\hline
\end{tabular}

\section{Introduction}

Clostridium perfringens is a gram positive, spore-forming anaerobic bacterium which causes a variety of enteric disorders in livestock leading to heavy economic loss. It produces an array of 17 different toxins across different hosts (Songer, 1996). It has been traditionally genotyped into five toxin types (A-E) based on the production of four major toxins $\alpha, \beta, \varepsilon$ and 1 (Songer, 1996). Apart from these major toxins, $C$. perfringens may also produce important subsidiary toxins like
Clostridium perfringens Enterotoxin (CPE) and $\beta 2$ toxin which are highly correlated with enteric disease conditions in humans as well as animals (Miyamoto et al., 2009; van Asten et al., 2010).

The $\beta 2$ toxin $(27.6 \mathrm{kDa})$ was first reported in 1997 from a piglet suffering from necrotic enteritis (Gibert et al., 1997) and since then presence of the gene (cpb2) coding for this toxin has been reported in isolates from pig, 
horse, cattle and small ruminants (van Asten et al., 2010). Presence of $c p b 2$ gene in isolates from piglets has particularly gained importance over the years due to its high correlation with piglet diarrhoea (Gibert et al., 1997; Klaasen et al., 1999; Bueschel et al., 2003). Pigs contribute around $2.01 \%$ of total livestock population in India. It is one of the major animal commodities in Assam comprising highest (15.89\%) population among the Indian states. Doom pigs are found in a few isolated pockets of Assam, which has been recognized as a breed very recently on $21^{\text {st }}$ June, 2016 with accession number "INDIA_PIG_0200_DOOM 09006" (New breeds registration, National Bureau of Animal Genetic Resources 2016). Doom pigs are known for its large body size, high prolificacy, disease resistance and sustenance in minimum input system (Zaman et al., 2014; Devi et al., 2017). Despite the high demand, the state has seen a decrease of $18.22 \%$ in the swine population from 2007 to 2012 (19th Livestock Census, 2012). This decrease in population may be attributed to poor healthcare and management practices in piglet raring (Roy et al., 2014). Here, we are highlighting two severe cases of necrotic enteritis caused by $\beta 2$ toxin of $C$. perfringens in piglets belonging to Doom breed.

\section{Materials and Methods}

Death of two piglets of around one month of age suffering from severe diarrhoea was reported from Kamrup district of Assam, India. Segments of their intestine collected at post-mortem were brought to the laboratory for further investigation. About $200 \mathrm{mg}$ of intestinal contents from both the samples were taken and treated with $50 \%$ ethanol for $30 \mathrm{~min}$ to remove any vegetative non-spore forming bacteria. $C$. perfringens was isolated on a blood agar plate with $5 \%$ defibrinated sheep blood in an anaerobic jar at $37^{\circ} \mathrm{C}$ for 48 hrs. Colonies showing a clear zone of haemolysis were further purified by subculturing and analysed by biochemical tests. Sugar fermentation test was carried out for dextrose, lactose, maltose, sucrose, dulcitol and mannitol. The isolates were also tested for MR-VP, $\mathrm{H}_{2} \mathrm{~S}$, catalase and indole production.

Toxin typing of the isolates was done by detection of four major toxin genes ( $c p a, c p b$, etx and iap) and two subsidiary toxin genes (cpb2 and cpe) by a multiplex PCR reaction (van Asten et al., 2009). Bacterial DNA was isolated using UltraClean ${ }^{\circledR}$ Bacterial DNA isolation kit and 200ng of isolated DNA was used as template. Qiagen Multiplex PCR master mix (Qiagen, Germany) was used for preparation of the reaction mixture with a final concentration of $0.2 \mu \mathrm{M}$ for all the primers, except $\mathrm{cpb} 2$, for which the primer concentration used was $0.4 \mu \mathrm{M}$. Primer sequences and respective product sizes are listed in table 1 . The PCR condition used was 15 min at $95{ }^{\circ} \mathrm{C}$ followed by 40 cycles of $30 \mathrm{~s}$ denaturation at $94{ }^{\circ} \mathrm{C}, 90$ s annealing at $53{ }^{\circ} \mathrm{C}$ and 90s extension at $72{ }^{\circ} \mathrm{C}$ and a final extension step of 10 min at $72^{\circ} \mathrm{C}$. Multiplex PCR results were analysed on 3\% agarose gel by performing electrophoresis with $80 \mathrm{~V}$ for 90 min.

For qPCR based enumeration of $C$. perfringens, total DNA was isolated from 200 mg of intestinal content using QIAamp ${ }^{\circledR}$ Fast DNA Stool Mini kit. In qPCR, $5 \mu$ of the isolated DNA was used as template in a reaction mixture containing $10 \mu \mathrm{l}$ of the Maxima Probe/ROX qPCR Master Mix (2X) (Thermo Fisher Scientific, USA), $1 \mu l$ each of forward primer (CP165F, $20 \mu \mathrm{M}$ stock) and reverse primer (CP269R, 20 $\mu \mathrm{M}$ stock), and $1 \mu \mathrm{l}$ of probe $\mathrm{CP} 187 \mathrm{~F}$ at $2 \mu \mathrm{M}$ concentration (Wise and Siragusa, 2005). The final reaction volume was made up to $20 \mu \mathrm{l}$ with NFW. Primers and probes used were: forward primer, CPerf165F (5'-CGCATAACGTTGA 
AAGATGG-3'); reverse primer: CPerf269R (5'-CCTTGGTA GGCCGTTACCC-3') and probe: CP187F (5'-[FAM]TCATCATTCAA CCAAAGGAGCAATCC [Iowa Black]-3'). The qPCR reactions were carried out in a Step One Plus real time thermal cycler (Thermo Fisher Scientific, USA) with the reaction condition as follows: initial denaturation 10 min step at $94^{\circ} \mathrm{C}$, followed by 45 cycles of denaturation at $94^{\circ} \mathrm{C}$ for $10 \mathrm{~s}$, annealing at $55^{\circ} \mathrm{C}$ for $20 \mathrm{~s}$, and extension at $70^{\circ} \mathrm{C}$ for $10 \mathrm{~s}$. A standard curve was prepared using a serial dilution of known concentration of $C$. perfringens genomic DNA. The $C$. perfringens load was determined by calculating it from the DNA quantity considering the molecular weight of $C$. perfringens genome (Wu et al., 2010).

\section{Results and Discussion}

Post-mortem examination of both the piglets showed intestinal necrotic lesions. Upon dissection, the internal lesions were found to be more severe (Fig. 1a,b). No other pathological alterations were reported in other vital organs.

Colonies showing a clear zone of hemolysis from both the samples were further investigated by biochemical assays. Acid and gas production was observed in sugar fermentation test for dextrose, maltose, sucrose and lactose, whereas no changes were observed with dulcitol and mannitol.

Isolates were also found to be MR-VP, catalase and indole test negative. Upon toxin typing by multiplex PCR, the isolates were found to be of type A with cpa(324bp) and cpb2 (548bp) genes (Fig. 1c). qPCR based $\mathrm{C}_{\mathrm{t}}$ value determination and subsequent comparison with the standard curve (Fig. $1 \mathrm{~d}, \mathrm{e})$ revealed a high load of $C$. perfringens $\left(1.89 \times 10^{6}\right.$ and $1.67 \times 10^{6}$ per gram) in the intestinal content.

Table.1 Oligo nucleotide primers and respective product size (van Asten et al., 2009)

\begin{tabular}{|c|c|c|c|}
\hline Toxin & Primer & Sequence $\left(5^{\prime}-3^{\prime}\right)$ & Product \\
\hline \multirow{2}{*}{$\alpha$} & cpa-F & GCTAATGTTACTGCCGTTGA & \multirow{2}{*}{324} \\
\hline & cpa-R & CCTCTGATACATCGTGTAAG & \\
\hline \multirow{2}{*}{$\beta$} & beta-F & GCGAATATGCTGAATCATCTA & \multirow{2}{*}{195} \\
\hline & beta- $\mathrm{R}$ & GCAGGAACATTAGTATATCTTC & \\
\hline \multirow{2}{*}{$\beta 2$} & beta2-F & AAATATGATCCTAACCAAM ${ }^{\mathrm{a} A A}$ & \multirow{2}{*}{548} \\
\hline & beta2-R & CCAAATACTY' ${ }^{\mathrm{T}}$ TATYGATGC & \\
\hline \multirow{2}{*}{$\varepsilon$} & epsilon-F & TGGGAACTTCGATACAAGCA & \multirow{2}{*}{376} \\
\hline & epsilon- $\mathrm{R}$ & AACTGCACTATAATTTCCTTTTCC & \\
\hline \multirow{2}{*}{$l$} & iota-F & AATGGTCCTTTAAATAATCC & \multirow{2}{*}{272} \\
\hline & iota- $\mathrm{R}$ & TTAGCAAATGCACTCATATT & \\
\hline \multirow{2}{*}{ Enterotoxin } & entero-F & TTCAGTTGGATTTACTTCTG & \multirow{2}{*}{485} \\
\hline & entero- $R$ & TGTCCAGTAGCTGTAATTGT & \\
\hline
\end{tabular}


Fig.1 (a,b) Intestinal section showing necrotic lesions (c) Gel electrophoresis 1: No template control, 2: Multiplex PCR product with band for cpa (324 bp) and beta2 (548 bp), 3: $100 \mathrm{bp}$

\section{DNA ladder}
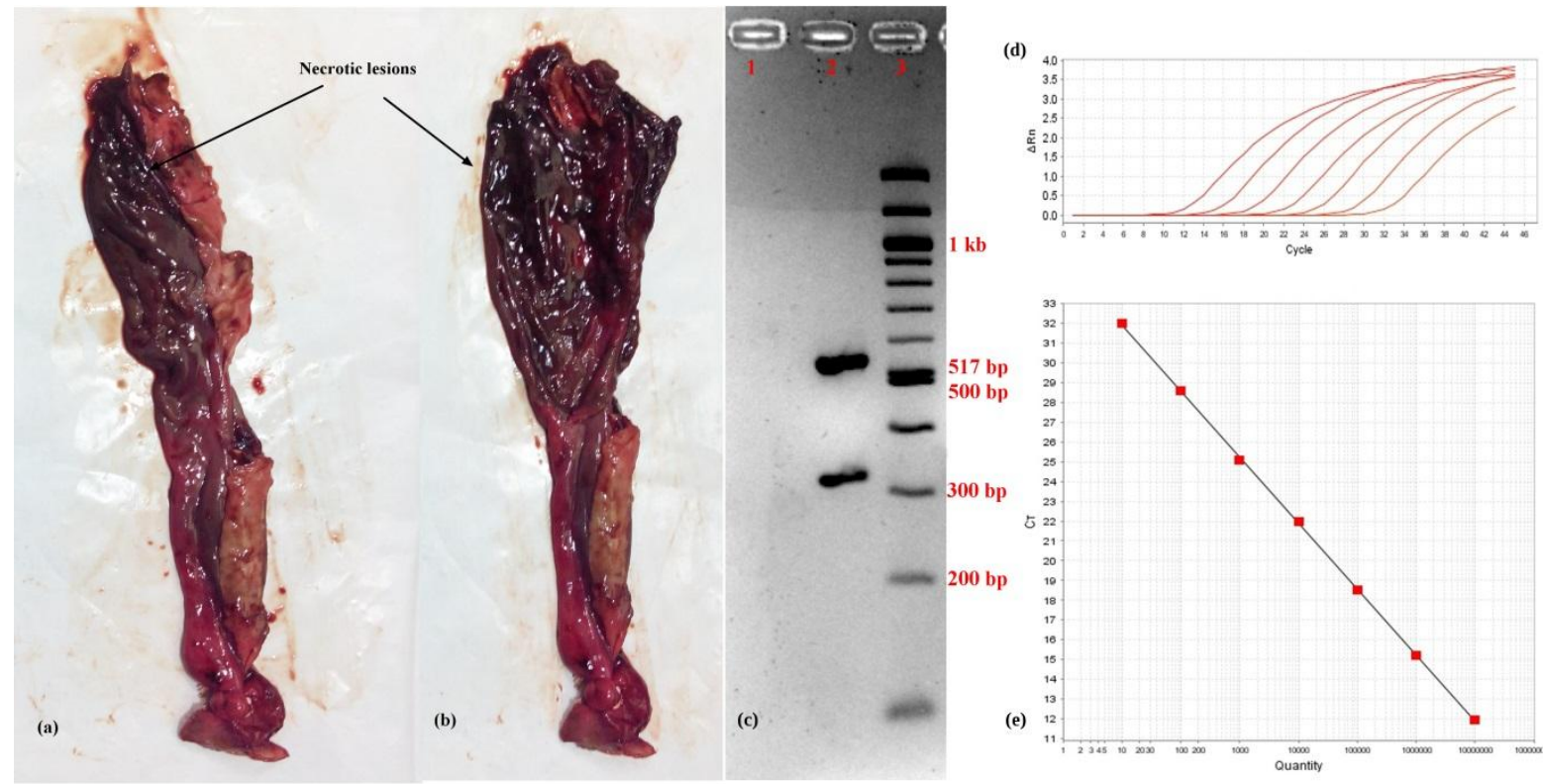

Necrotic enteritis followed by diarrhoea is a serious problem in piglets. The present investigation demonstrated a classic case of $\beta 2$ toxin pathogenesis by Type A $C$. perfringens causing fatal necrotic enteritis. This is the first report of fatal necrotic enteritis caused by $\beta 2$ toxin producing $C$. perfringens in piglets of Doom breed from this region. Doom pigs appear to be disease resistant compared to other breeds of pig and can be reared with minimal input. Disease conditions caused by $\beta 2$ toxin in such a naturally resistant breed are significant in terms of its pathogenesis. Although there have been several reports of $\beta 2$ toxin producing $C$. perfringens causing up to $100 \%$ mortality in piglets, no report could be traced out in the available literature on quantification of $C$. perfringens in the intestinal content under such conditions. As $\beta 2$ toxin positive Type A $C$. perfringens are commonly present in the piglet intestine, quantification carries distinctive diagnostic value. In this study, an increase of $C$. perfringens load up to $2.32 \mathrm{x}$ $10^{6}$ times was observed compared to that in healthy piglets reported earlier (Farzan et al., 2013). This high load of $C$. perfringens could be related to production of high amount of beta2 toxin which led to severe necrotic enteritis.

\section{Acknowledgement}

Authors would like to thank Dr. MichelRobert Popoff and Dr. Phillipe Bouvet, Anaerobe Bacteria and Toxins Laboratory, Pasture Institute, Paris for kindly providing the reference DNA samples. Authors are also thankful to Department of Biotechnology, Govt. of India and the State Biotech Hub (Assam) for the financial and laboratory support.

Conflict of Interest: The authors declare that they have no conflict of interest.

\section{References}

Bueschel DM, Jost BH, Billington SJ, et al, 2003. Prevalence of cpb2, encoding 
beta2 toxin, in Clostridium perfringens field isolates: Correlation of genotype with phenotype, Vetetinary Microbiology 94, 121-129

Devi B, Laskar S, Borah P, et al., 2017. Sequencing and phylogenetic analysis of the SLC11Al gene in pigs, J Applied Animal Research 45, 494497

Farzan A, Kircanski J, DeLay J, et al, 2013. An investigation into the association between cpb2-encoding Clostridium perfringens type $\mathrm{A}$ and diarrhea in neonatal piglets, Canadian Journal of Veterinary Research 77, 45-53.

Gibert M, Jolivet-Renaud C, Popoff MR, 1997. Beta2 toxin, a novel toxin produced by Clostridium perfringens, Gene 203,65-73.

Klaasen HLBM, Molkenboer MJCH, Bakker J, et al., 1999. Detection of the $\beta 2$ toxin gene of Clostridium perfringens in diarrhoeic piglets in The Netherlands and Switzerland, FEMS Immunology and Medical Microbiology 24, 325-332.

Miyamoto K, Li J, McClane B, 2009. Enterotoxigenic Clostridium perfringens: Detection and Identification, Microbes and Environment 27, 343-349.

Roy B, Kumar A, Lakhani GP, Jain A, 2014. Causes of pre-weaning pig mortality in India. Scholars Journal of Agricultural Science 4,485-493.

Songer JG,1996. Clostridial enteric diseases of domestic animals. Clinical Microbiology Review 9,216-234.

van Asten AJAM, Nikolaou GN, Grone A,
2010. The occurrence of cpb2toxigenic Clostridium perfringens and the possible role of the $\beta 2$-toxin in enteric disease of domestic animals, wild animals and humans. The Veterinary Journal 183,135-140.

van Asten AJAM, van der Wiel CW, Nikolaou G, et al., 2009. A multiplex PCR for toxin typing of Clostridium perfringens isolates. Veterinary Microbiology 136,411-412.

Wise MG, Siragusa GR, 2005. Quantitative Detection of Clostridium perfringens in the Broiler Fowl Gastrointestinal Tract by Real-Time PCR Quantitative Detection of Clostridium perfringens in the Broiler Fowl Gastrointestinal Tract by Real-Time PCR. Applied Environmental Microbiology 71, 3911-3916.

Wu SB, Rodgers N, Choct M, 2010. Optimized necrotic enteritis model producing clinical and subclinical infection of Clostridium perfringens in broiler chickens. Avian Diseases 54,1058-1065.

Zaman G, Laskar S, Ferdoci AM, et al., 2014. Molecular characterization of Doom pigs using microsatellite markers. African Journal Biotechnology 13: 3017-3022.

New breeds registration, National Bureau of Animal Genetic Resources. http://www.nbagr.res.in/registeredbree d.html. Accessed 23 Sep 2016

19th Livestock Census-2012, Ministry of Agriculture, Department of Animal Husbandry, Dairying and Fisheries, Govt of India.

\section{How to cite this article:}

Md. Iftikar Hussain, Probodh Borah, Isfaqul Hussain, Rajeev Kumar Sharma and Mohan Chandra Kalita. 2017. Necrotic Enteritis by Beta2toxin-Producing Clostridium perfringens in Doom Pigs of Assam, India. Int.J.Curr.Microbiol.App.Sci. 6(5): 1872-1876. doi: https://doi.org/10.20546/ijcmas.2017.605.206 